\title{
Deletion of the entire interferon- $\gamma$ receptor 1 gene causing complete deficiency in three related patients
}

\author{
Inge C. de Vor ${ }^{1}$ Pomme M. van der Meulen ${ }^{2}$ - Vincent Bekker ${ }^{1}$. Els M. Verhard ${ }^{3}$. \\ Martijn H. Breuning ${ }^{4}$ Esther Harnisch ${ }^{2}$ • Maarten J. D. van Tol ${ }^{1}$. \\ Jantien W. Wieringa ${ }^{2}$ - Esther van de Vosse $^{3}$ - Robbert G. M. Bredius ${ }^{1}$
}

Received: 23 November 2015 / Accepted: 14 February 2016 / Published online: 1 March 2016

(C) The Author(s) 2016. This article is published with open access at Springerlink.com

\begin{abstract}
Purpose Complete interferon- $\gamma$ receptor 1 (IFN- $\gamma \mathrm{R} 1)$ deficiency is a primary immunodeficiency causing predisposition to severe infection due to intracellular pathogens. Only 36 cases have been reported worldwide. The purpose of this article is to describe a large novel deletion found in 3 related cases, which resulted in the complete removal of the IFNGRI gene.

Methods Whole blood from three patients was stimulated with lipopolysaccharide (LPS) and IFN- $\gamma$ to determine production of tumor necrosis factor (TNF), interleukin-12 p40 (IL-12p40) and IL-10. Expression of IFN- $\gamma \mathrm{R} 1$ on the cell membrane of patients' monocytes was assessed using flow cytometry. IFNGRI transcript was analyzed in RNA and the gene and adjacent regions were analyzed in DNA. Finally, IL22RA2 transcript levels were analyzed in whole blood cells and dendritic cells.
\end{abstract}

Inge C. de Vor, Pomme M. van der Meulen, Esther van de Vosse, and Robbert G. M. Bredius shared first and last authors.

Electronic supplementary material The online version of this article (doi:10.1007/s10875-016-0244-y) contains supplementary material, which is available to authorized users.

Robbert G. M. Bredius

r.g.m.bredius@lumc.nl

1 Department of Pediatrics, Leiden University Medical Center, Albinusdreef 2, 2333 ZA Leiden, The Netherlands

2 Department of Pediatrics, Medical Center Haaglanden, Lijnbaan 32, 2512 VA The Hague, The Netherlands

3 Department of Infectious Diseases, Leiden University Medical Center, Albinusdreef 2, 2333 ZA Leiden, The Netherlands

4 Department of Clinical Genetics, Leiden University Medical Center, Albinusdreef 2, 2333 ZA Leiden, The Netherlands
Results There was no expression of the IFN- $\gamma \mathrm{R} 1$ on the monocytes. Consistent with this finding, there was no IFN- $\gamma$ response in the whole blood assay as measured by effect on LPS-induced IL-12p40, TNF and IL-10 production. A 119.227 nt homozygous deletion on chromosome $6 q 23.3$ was identified, removing the IFNGRI gene completely and ending $117 \mathrm{nt}$ upstream of the transcription start of the IL22RA2 gene. Transcript levels of IL22RA2 were similar in patient and control.

Conclusions We identified the first large genomic deletion of IFNGR 1 causing complete IFN- $\gamma \mathrm{R} 1$ deficiency. Despite the deletion ending very close to the IL22RA2 gene, it does not appear to affect $I L 22 R A 2$ transcription and, therefore, may not have any additional clinical consequence.

Keywords MSMD · IFN- $\gamma \mathrm{R} 1$ deficiency · IFNGR1 . Mycobacterium fortuitum $\cdot \mathrm{EBV} \cdot$ IL22RA2

\section{Introduction}

Complete interferon- $\gamma$ receptor 1 (IFN- $\gamma \mathrm{R} 1)$ deficiency is an autosomal recessively inherited immunodeficiency, characterized by predisposition to infections with intracellular pathogens, in particular mycobacteria. This rare genetic defect disrupts the interferon- $\gamma$ (IFN- $\gamma$ ) pathway, leading to one of the 19 genetic etiologies of Mendelian Susceptibility to Mycobacterial Diseases (MSMD) [1-3]. Complete IFN- $\gamma$ R 1 and complete IFN- $\gamma$ R2 deficiency, represent the most severe phenotypes of MSMD, whereas partial IFN- $\gamma \mathrm{R} 1$ deficiency is associated with a later onset and milder disease course.

Most commonly, patients with complete IFN- $\gamma$ R1 deficiency present with lymphadenopathy, hepatosplenomegaly and intermittent fever in early childhood, caused by infection 
with weakly virulent, mostly environmental mycobacteria such as Mycobacterium avium or the vaccine strain Mycobacterium bovis bacillus Calmette-Guérin (BCG) [2]. Furthermore, patients with a complete defect appear to be prone to develop malignancies [4-6]. Hematopoietic stem cell transplantation (HSCT) is required to restore normal immune function. Unfortunately graft failure rates are high $[7,8]$ and consequently, the overall prognosis of patients with complete IFN- $\gamma \mathrm{R} 1$ deficiency remains poor.

The IFN- $\gamma \mathrm{R} 1$ gene (IFNGRI) is located on chromosome $6 q 23.3$ and stretches over $22 \mathrm{~kb}$. Twenty-seven unique mutations causing complete IFN- $\gamma \mathrm{R} 1$ deficiency have been identified so far. These are all small variations, with the largest deletion being only 22 nucleotides long (see Table 1). This is the first description of a large genomic deletion, removing IFNGRI entirely and causing complete IFN- $\gamma \mathrm{R} 1$ deficiency in three related patients.

\section{Case Reports}

A 1-year-old girl (patient 1) of Turkish origin was seen in the outpatient department with unilateral cervical lymphadenitis, existing for 1 month despite treatment with flucloxacillin by her family doctor. Apart from a persisting rhinitis the child had no other complaints, especially no fever, night sweats, weight loss, orthopnea or signs of hemorrhagic diathesis. There was no history of animal contact or visits to foreign countries. Her medical history included two episodes of respiratory tract infections at the age of 6 and 7 months, requiring admission to the hospital. Oxygen therapy, oral macrolide antibiotics and bronchodilators were given. Chest X-rays showed bilateral consolidations during the first admission, which were resolved a month later. Beclomethasone inhalation therapy was started after discharge. She was vaccinated according to the Dutch national program, which does not include BCG vaccine. Parents were consanguineous (Fig. 1a), but otherwise the family medical history was unremarkable.

Physical examination revealed multiple small cervical lymph nodes and one enlarged left pre-sternocleidomastoid node $(4 \times 2 \mathrm{~cm})$ without fluctuation or redness of the overlying skin. Laboratory analysis revealed a leukocytosis with increased granulocyte and lymphocyte numbers without leukemic blasts, a mild anemia and a normal thrombocyte count. Chest X-ray was normal. Serologic tests for streptococcus, Bartonella sp., toxoplasmosis, Epstein-Barr virus and cytomegalovirus were negative. A bacterial infection was suspected and amoxicillin/clavulanic acid was administered.

In light of progressive enlargement of the cervical lymph node $(4 \times 6 \mathrm{~cm})$ and appearance of supraclavicular nodes in the next weeks, other diagnoses, such as malignancy and (atypical) mycobacterial infection were considered. Screening for anti-nuclear antibodies, sarcoidosis, human immunodeficiency virus, germ cell tumor and neuroblastoma was negative. Ultrasound did not show abscess formation or intra-abdominal lymphadenopathy. Quantitative immunoglobulin levels revealed marginally raised IgM and IgA levels, whereas $\mathrm{IgG}$ level was normal. Peripheral blood Tlymphocyte counts were performed and showed increased CD3 and CD4 counts and CD4 effector-memory population, whereas the naïve T-cells were mildly decreased. The tuberculin skin test showed an induration of $7.0 \mathrm{~mm}$. The result of the IFN- $\gamma$ release assay (QuantiFERON ${ }^{\circledR}$ ) showed high values for the specific mycobacterial antigens, however, the assay was interpreted as invalid because of very high IFN- $\gamma$ values obtained for the negative control $(64 \mathrm{IU} / \mathrm{ml}$, normal $<0.35 \mathrm{IU} / \mathrm{ml})$. The high IFN- $\gamma$ in the negative control can however be indicative of a complete IFN- $\gamma$ R defect. Fine needle aspiration of the cervical lymph node showed nonspecific inflammation. Hence, bone marrow aspiration and lymph node excision were performed. Apart from nonspecific reactive inflammation of the lymph node, no histologic abnormalities, especially no granuloma formation or malignancy, were noted. Bone marrow examinations revealed reactive changes only with no evidence of malignant infiltration. After 2 weeks lymph node cultures became positive for Mycobacterium fortuitum. Treatment was started with ciprofloxacin and co-trimoxazole, eventually resulting in almost complete normalization of all laboratory parameters. The negative control in the QuantiFERON ${ }^{\circledR}$ test decreased to $2.6 \mathrm{IU} /$ $\mathrm{ml}$ (normal $<0.35 \mathrm{IU} / \mathrm{ml}$ ). Importantly, the clinical condition of the patient gradually improved.

Several weeks later the 3.5-year-old and almost 2-year-old female cousins (patient 2 and 3, respectively) presented with bilateral cervical lymphadenitis, which had been evident for almost 2 weeks. Accompanying symptoms were rhinitis, cervical pain and low-grade fever, which resolved spontaneously. Apart from one episode of bronchial hyper-reactivity (patient 2 ) and rotavirus infection (patient 3 ) their medical history was unremarkable. No BCG vaccine had been administered. Their parents were first cousins and from the same consanguineous Turkish family (Fig. 1a).

Physical examination revealed hepatosplenomegaly and bilateral enlarged lymph nodes (patient 2: mid-jugular left side $3.0 \times 1.5 \mathrm{~cm}$ and right side $3.5 \times 3.0 \mathrm{~cm}$; patient 3 : upper-jugular left side $3.0 \times 2.0 \mathrm{~cm}$ and right side $2.0 \times 1.0$ ) without fluctuation or redness. Laboratory analyses showed elevated inflammatory parameters (ESR, CRP and leukocytosis) and anemia in patient 2. Peripheral blood T-lymphocyte counts showed increased CD3 and CD4 effector-memory population in patient 2 and an increased CD8 effector-memory population in patient 3 . Plasma EBV DNA analysis and EBV serology indicated primary EBV infection in both patients (i.e. patient 2: $\operatorname{IgG}$ EBV-VCA and IgG EBV-EBNA positive; patient 3: EBV PCR 300 copies $/ \mathrm{ml}$ at admission becoming negative in 


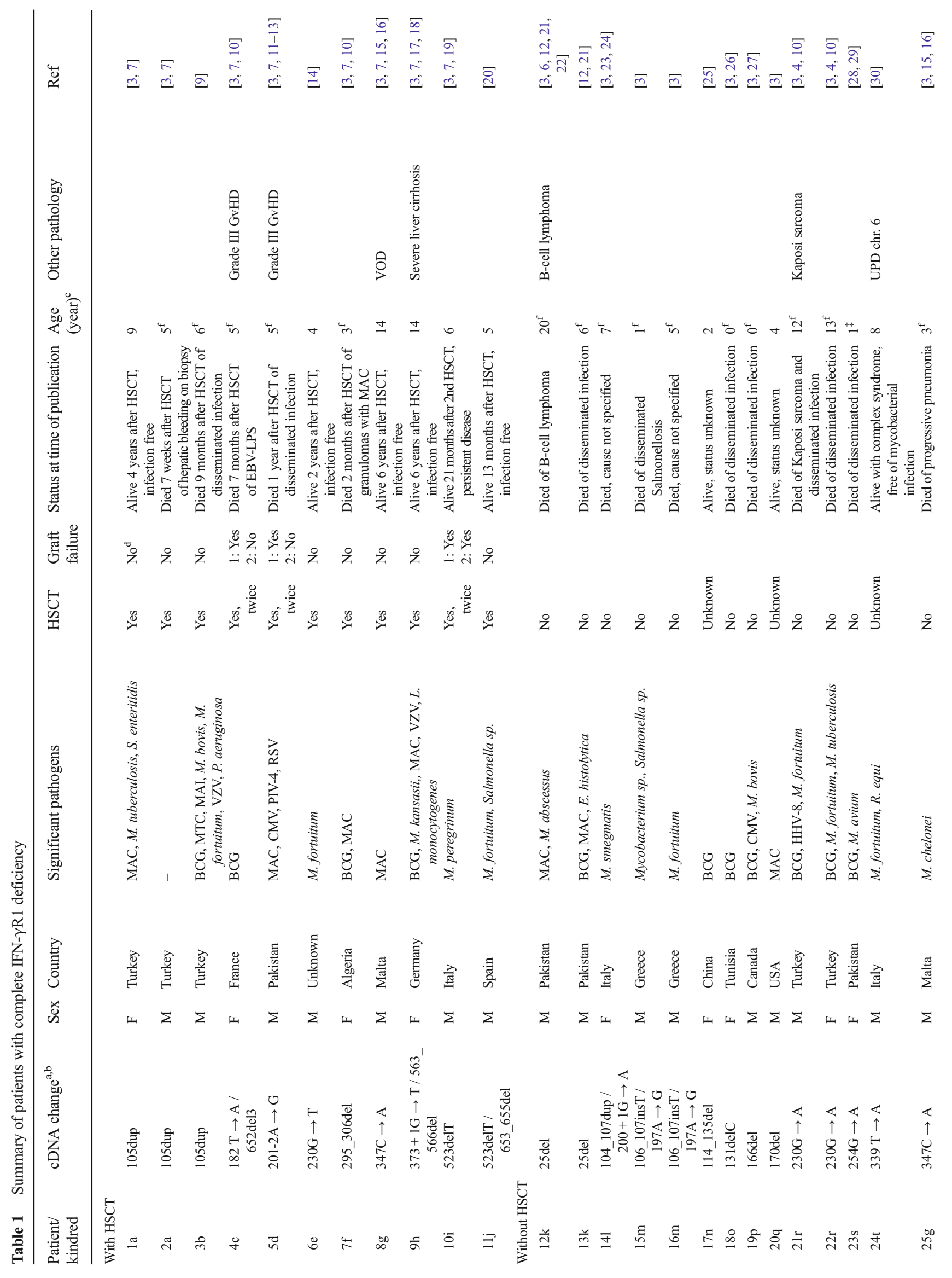




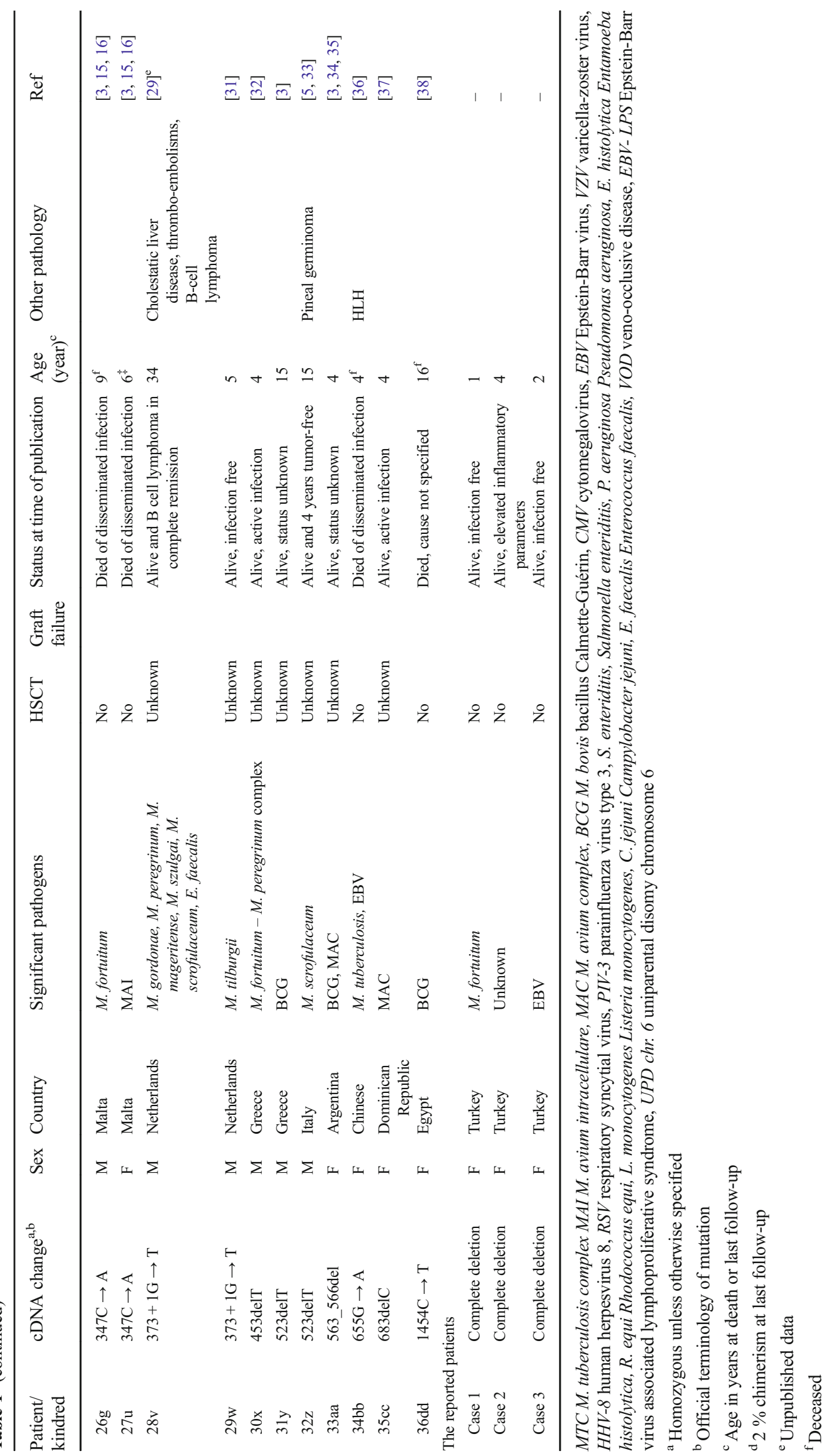


Fig. 1 Pedigree, immunological assays and genetic analysis of patients. Family tree of patients 1 , 2 and 3 (a). In vitro TNF production in response to stimulation with LPS plus various concentrations of IFN- $\gamma$ in patient 1 and healthy control (b). Flow cytometry showing absent cell surface expression of IFN- $\gamma$ R1 (GIR-94 antibody, BD

Biosciences) on monocytes of patient 2 (c). Large homozygous deletion on chromosome 6q23.3 identified with PCR and sequencing, removing the entire IFN- $\gamma \mathrm{R} 1$ gene (IFNGRI) and surrounding region $(\mathbf{d})$. Deletion terminates $117 \mathrm{nt}$ upstream of the transcription start of IL22RA2 (not to scale). The first and last nucleotides of the deletion are: $137,173,766$ and 137,292,992 H. sapiens chromosome 6, GRCh38.p2 Primary Assembly a
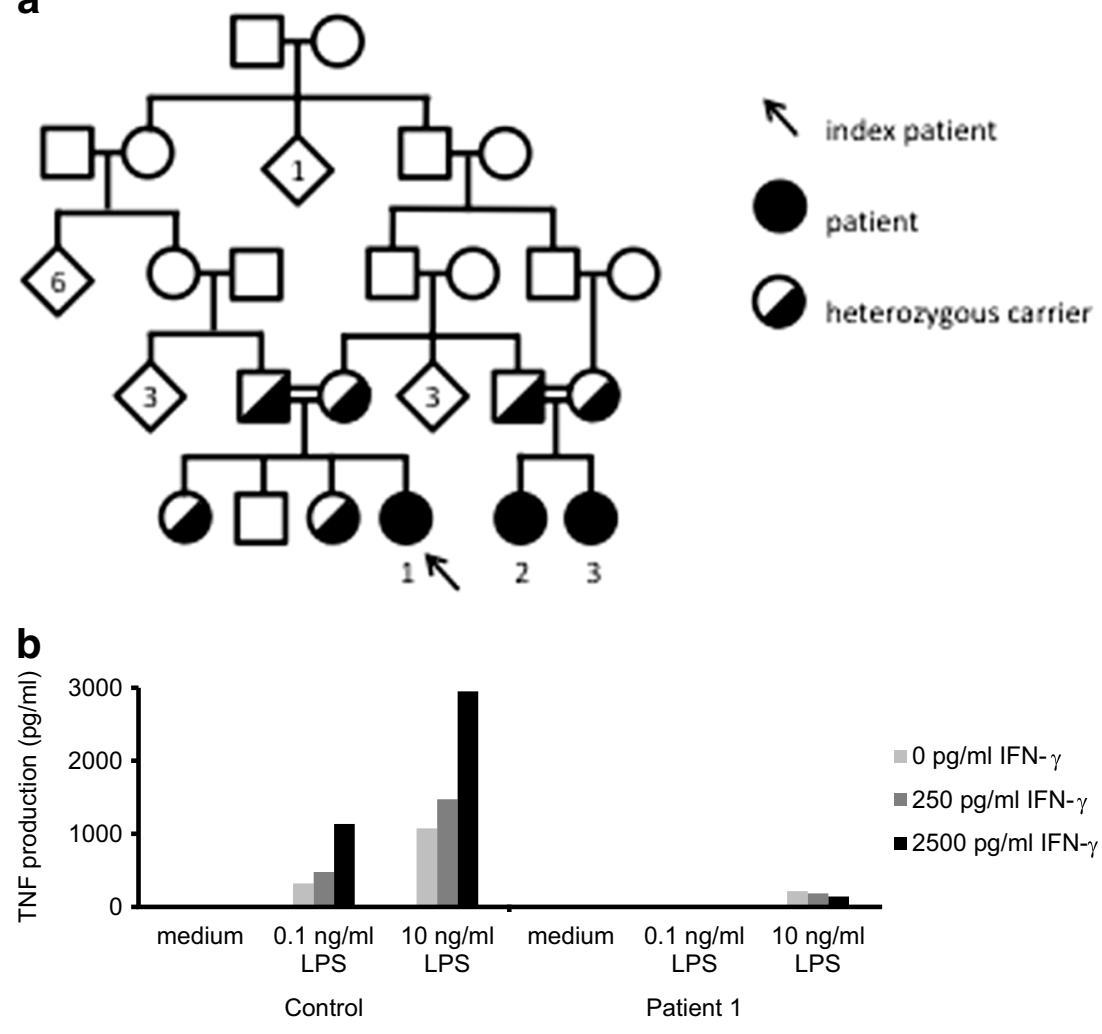

C
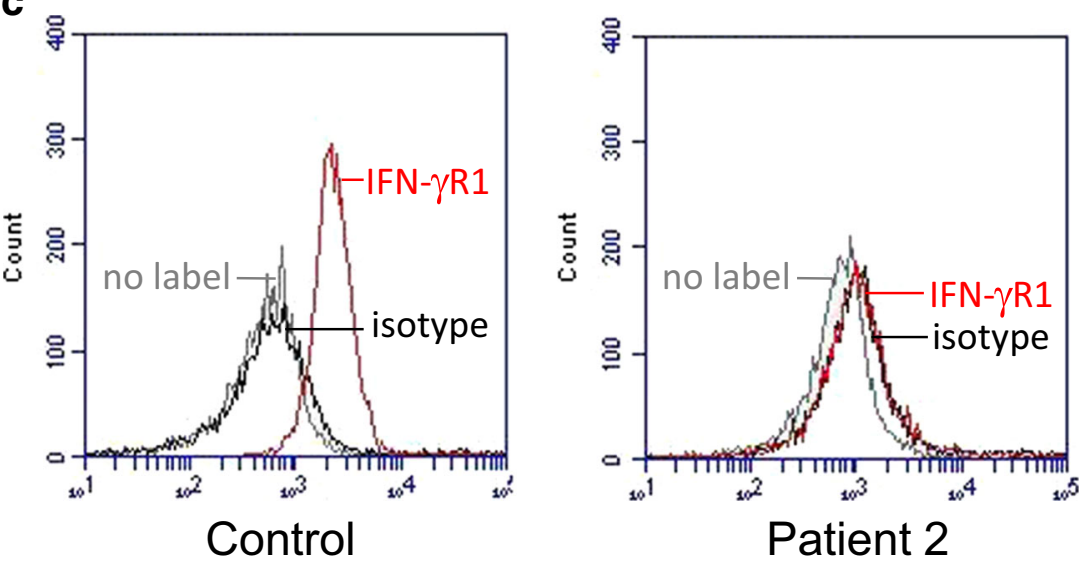

d

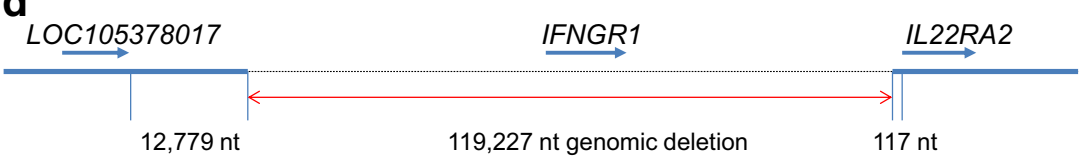

association with seroconversion of IgM to IgG EBVVCA). QuantiFERON ${ }^{\circledR}$ test showed similar results with high negative control values in the IFN- $\gamma$ release assay as in patient 1. Ultrasound analysis confirmed the presence of hepatosplenomegaly, without intra-abdominal lymphadenopathy nor abscess formation of the cervical nodes.
Fine needle aspiration of the cervical lymph nodes showed no mycobacterial infection or other abnormalities.

Patients 2 and 3 were closely monitored without prophylaxis for mycobacterial diseases. During this follow-up a skin infection developed in patient 2 due to varicella zoster virus and in patient 3 due to Staphylococcus aureus, which were 
successfully treated with valaciclovir and flucloxacillin, respectively. The treatment of patient 3 required two days hospitalization for intravenous flucloxacillin. Otherwise the clinical courses were unremarkable. Although the size of the lymph nodes decreased over time in both patients, the hepatosplenomegaly and inflammatory parameters were persistently elevated for several months in the eldest (patient 2) in contrast to her younger sister (patient 3 ), in whom spontaneous resolution was observed over a period of 4 weeks. Because of the persisting lymphadenopathy in patient 2 , bone marrow aspiration and lymph node excision were recently performed. Very similar to the observation in patient 1 , non-specific reactive inflammation of the lymph node and no histologic abnormalities, especially no granuloma formation or malignancy, were noted. EBV in situ hybridization was negative, and no other (mycobacterial) infection could be detected.

IFN- $\gamma$ concentrations were determined in serum samples of the patients by Luminex assay. These were on the day of their first visit our clinic 2330, 1144 and $1568 \mathrm{pg} / \mathrm{ml}$ (normal 7$124 \mathrm{pg} / \mathrm{ml}$ ) in patient 1,2 and 3, respectively. During followup (after 6.5, 3.5 and 3.5 months) these IFN- $\gamma$ concentrations decreased to 298,707 and $428 \mathrm{pg} / \mathrm{ml}$ in patient 1, 2 and 3, respectively.

\section{Materials and Methods}

\section{Immunological Assays}

Whole blood assay and IFN- $\gamma \mathrm{R} 1$ expression analysis were performed as previously described $[39,40]$.

\section{Genetic Analysis of IFNGRI}

DNA and RNA were isolated from whole blood; cDNA was synthesized from RNA with SuperScript III (Invitrogen, Bleiswijk, the Netherlands). Reverse transcription polymerase chain reaction (RT-PCR) of the IFNGR1 transcript from cDNA was performed (primers and conditions available on request). PCRs were performed to amplify all exons of IFNGR1 from genomic DNA. Various primer sets were subsequently designed to amplify the genomic region around IFNGR1 and to determine the extent of the deletion. The primers that were found to cover the deletion were DEL307F 5'-AAAGCTTGGTTTCATGCTCTAA-3' and DEL307R 5'-GGGACGCCATGTTATGTTTT-3'. These are located at 137293106-137293085 and 137173480137173499, respectively, on Homo sapiens chromosome 6, GRCh38.-2 Primary Assembly.
Analysis of IL22RA2 Transcription by Dendritic Cells and Whole Blood Cells

PBMCs isolated from whole blood were cultured in IMDM (containing $10 \%$ human serum, glutamine, penicillin, streptomycin) allowing monocytes to adhere to the flask surface. Non-adherent cells were washed away after $18 \mathrm{~h}$. Monocytes were cultured for 4 days with $20 \mathrm{ng} / \mathrm{ml}$ GM-CSF (Sanquin, Amsterdam, NL) and $20 \mathrm{ng} / \mathrm{ml}$ IL-4 (Peprotech, London, UK) to induce differentiation to dendritic cells and $100 \mathrm{nM}$ retinoid derivative AM580 (Sigma, St. Louis, MI, USA) to induce IL22RA2 transcription. Cells were washed and cultured for another 3 days in IMDM containing $10 \%$ fetal calf serum, glutamine, penicillin, streptomycin, GM-CSF, IL-4 and AM580. RNA was isolated, cDNA was synthesized with SuperScript III (Invitrogen) and qRT-PCR was performed to detect TBP (reference gene) and IL22RA2 transcripts (primers and conditions available on request). qRT-PCR was also performed in RNA isolated from whole blood cells.

\section{Results}

\section{No IFN- $\gamma$ Response in patients' Cells and no IFN- $\gamma$ R1 Expression on patients' Monocytes}

To determine whether the IFN- $\gamma$ pathway was functional, we stimulated whole blood of patient 1 with LPS and IFN- $\gamma$. TNF production was low in response to LPS and not upregulated by the addition of IFN- $\gamma$ in various concentrations (Fig. 1b). Furthermore, there was no upregulation of IL-12p40 or downregulation of IL-10 in response to the addition of IFN- $\gamma$ (data not shown). The patient is capable of producing cytokines in the same whole blood assay, as illustrated by the IL-10 production in response to LPS (Supplemental Figure 1). Results of patients 2 and 3 were identical. Flow cytometry showed that cell surface expression of IFN- $\gamma \mathrm{R} 1$ on patients' monocytes was absent (Fig. 1c).

\section{The Patients are Homozygous for a Large Deletion Removing IFNGR1 Completely}

Subsequent analysis of RNA of patient 1 showed that IFNGRI transcripts were absent and IFNGRI exons could not be amplified from genomic DNA of the patient. Using various primer combinations in the regions flanking the IFNGR1 gene, we were able to establish that a genomic deletion of $119.227 \mathrm{nt}$ was present (Fig. 1d). The first and last nucleotides of the deletion are 137173766 and 137292992 (Homo sapiens chromosome 6, GRCh38.p2 Primary Assembly) encompassing the entire IFNGRI gene but leaving the flanking genes LOC105378017 (uncharacterized gene) and IL22RA2 (encoding a soluble IL-22 receptor, also known 
as IL-22BP) intact. The deletion was homozygously present in all three patients and heterozygously in all four parents and two of the three siblings of patient 1 (Fig. 1a).

\section{Similar IL22RA2 Transcript Levels in Patient 2 and Control}

Because the genomic deletion ended only $117 \mathrm{nt}$ upstream of the transcription start of IL22RA2 we hypothesized this deletion could affect its transcription. Therefore, we analyzed IL22RA2 transcripts by RT-PCR in RNA isolated from dendritic cells stimulated with the retinoid derivative AM580, which is known to upregulate IL22RA2 transcription. In both patient 2 and a control IL22RA2 transcript variant 2 (lacking exon 4, containing exon 6) was the most abundant transcript, while IL22RA2 transcript variant 1 (containing all exons) was also present. IL22RA2 transcript variant 3 (lacking exon 4 and 6) was not detected in the samples. To determine whether the promoter is not continuously active we assessed whether IL22RA2 transcripts were detectable in whole blood cells. In RNA isolated from whole blood cells IL22RA2 transcripts were not detectable in samples from the three patients and a control (data not shown). qRT-PCR for IL22RA2 showed that the ratio between patient/control transcript levels is 1,92 in the AM580-stimulated dendritic cells and confirmed that in whole blood IL22RA2 transcripts are undetectable in the patient and control.

\section{Discussion}

We describe three related patients with complete IFN- $\gamma \mathrm{R} 1$ deficiency. They presented between 1 and 4 years of age with persistent or marked cervical lymphadenopathy as the main symptom. Lymph node tissue from patient 1 cultured $M$. fortuitum as the causative pathogen and primary EBV infection was found in patients 2 and 3 .

To date, only 36 cases of complete IFN- $\gamma \mathrm{R} 1$ deficiency have been reported. These patients are summarized in Table 1. All but one patient developed mycobacterial infection, including BCG post vaccination infections in fourteen cases. In addition, other significant pathogens were identified in approximately one third of the cases. The disease course of these infections was either comparable (e.g. EBV) or more severe (e.g. Salmonellae, Pseudomonas aeruginosa, Listeria monocytogenes) than observed in immunocompetent subjects. Furthermore, late-onset malignancy (pineal germinoma, Kaposi sarcoma and two cases of B-cell lymphoma) following diagnosis developed in four cases (Table 1: patients $32 \mathrm{z}, 21 \mathrm{r}$, $12 \mathrm{k}$ and $28 \mathrm{v}$, respectively).

The clinical presentation of patient 1 is similar to previously reported cases. $M$. fortuitum has been identified in eight previous cases, and is therefore a well-known pathogen causing disease in patients with complete IFN- $\gamma \mathrm{R} 1$ deficiency (Table 1). Furthermore, the very high serum levels of IFN- $\gamma$ as detected in the negative control of the Quantiferon test and in the Luminex assay are correlated with the lack of IFN- $\gamma$ R1 expression on the cell surface. This phenomenon has been described before in patients with complete IFN- $\gamma \mathrm{R} 1$ or IFN- $\gamma$ R2 deficiency [41]. Patients 2 and 3 presented with cervical lymphadenopathy and splenomegaly due to primary EBV infection, which has not been reported before as a first presentation in patients with complete IFN- $\gamma \mathrm{R} 1$ deficiency. The clinical disease course of the EBV infection was relatively unremarkable, but hepatosplenomegaly and inflammatory parameters (i.e. elevated ESR, CRP, leukocytosis, lymphocytosis, and hypergammaglobulinemia) were more pronounced compared to EBV infection in subjects with normal immune function. In patient 2 these laboratory parameters remained abnormal for over 4 months. When compared to the previously described cases this benign clinical phenotype is likely due to lack of exposure thus far in these very young patients to pathogenic mycobacteria.

Twenty-seven different mutations causing complete IFN- $\gamma \mathrm{R} 1$ deficiency have been reported (Leiden Open Variation Database, www.lovd.nl/IFNGR1 and Table 1). These mutations are single nucleotide variations, small duplications, insertions or deletions. The largest reported genomic deletion was only $22 \mathrm{nt}$ long (patient $17 \mathrm{n}$, Table 1). Complete absence of IFNGR1 due to a large deletion has not been reported previously. It remains unclear whether the size of the deletion (119.227 nt) has additional clinical consequences other than complete IFN- $\gamma \mathrm{R} 1$ deficiency. No coding regions besides IFNGRI are known to be located in the area of the deletion. However, the deletion terminates $117 \mathrm{nt}$ upstream of the transcription start of the IL22RA2 gene, raising suspicion that binding of transcription-regulating factors might be affected. Transcription of IL22RA2 leads to production of IL22 binding protein (IL-22BP), a soluble receptor, which is capable of binding and inactivating IL-22 [42]. IL-22BP is produced by dendritic cells [43]. We were able to detect $I L 22 R A 2$ transcription in response to retinoid stimulation of the dendritic cells that was similar between patient and control in both abundance and transcript variants present. Transcript variant 2 , encoding the IL-22BP isoform which efficiently binds and inhibits IL-22 [42, 44], was the most abundant transcript detected. To determine whether the promoter is not continuously active we also assessed whether IL22RA2 transcripts were detectable in whole blood cells. This was neither the case in patients nor in control RNA. Together these results suggest that IL22RA2 transcription is not affected.

At time of publication, infectious parameters of patient 2 remain elevated several months after primary EBV infection, while bacterial cultures of lymph node and blood are repeatedly negative. Patients 1 and 3 are in good clinical condition, without signs of active infection. Hematopoietic stem cell 
donor searches are in progress in order to facilitate future HSCT for all three children. Unfortunately, graft failure has been reported in approximately one third of transplanted cases (Table 1). This increased rate is most likely due to high plasma concentrations of IFN- $\gamma$ [41], which has anti-hematopoietic activity [45]. Options for reducing plasma IFN- $\gamma$ around HSCT with anti-IFN- $\gamma$ monoclonal antibodies are currently being explored.

In conclusion, we report three related cases of complete IFN- $\gamma \mathrm{R} 1$ deficiency caused by a novel large genomic deletion, removing IFNGRI entirely and ending close to the IL22RA2 gene. The disease course of the patients reported here was relatively unremarkable and similar to previously reported cases of complete IFN- $\gamma \mathrm{R} 1$ deficiency, except for primary EBV infection as the presenting infection in two of three patients.

Acknowledgments The authors wish to thank Dr Jaap Bakker for the QuantiFERON ${ }^{\circledR}$ analysis, Els van Beelen for performing the Luminex analysis and Dr Lynne Ball for critically reading the manuscript.

\section{Compliance with Ethical Standards}

Conflict of Interest The authors declare that they have no conflict of interest.

Open Access This article is distributed under the terms of the Creative Commons Attribution 4.0 International License (http:// creativecommons.org/licenses/by/4.0/), which permits unrestricted use, distribution, and reproduction in any medium, provided you give appropriate credit to the original author(s) and the source, provide a link to the Creative Commons license, and indicate if changes were made.

\section{References}

1. Bustamante J, Boisson-Dupuis S, Abel L, Casanova JL. Mendelian susceptibility to mycobacterial disease: genetic, immunological, and clinical features of inborn errors of IFN-gamma immunity. Semin Immunol. 2014;26(6):454-70.

2. van de Vosse E, van Dissel JT, Ottenhoff TH. Genetic deficiencies of innate immune signalling in human infectious disease. Lancet Infect Dis. 2009;9(11):688-98.

3. Dorman SE, Picard C, Lammas D, Heyne K, Van Dissel JT, Baretto $\mathrm{R}$, et al. Clinical features of dominant and recessive interferon gamma receptor 1 deficiencies. Lancet. 2004;364(9451):2113-21.

4. Camcioglu Y, Picard C, Lacoste V, Dupuis S, Akcakaya N, Cokura $\mathrm{H}$, et al. HHV-8-associated Kaposi sarcoma in a child with IFNgammaR1 deficiency. J Pediatr. 2004;144(4):519-23.

5. Taramasso L, Boisson-Dupuis S, Garre ML, Bondi E, Cama A, Nozza P, et al. Pineal germinoma in a child with interferongamma receptor 1 deficiency. case report and literature review. J Clin Immunol. 2014;34(8):922-7.

6. Bax HI, Freeman AF, Anderson VL, Vesterhus P, Laerum D, Pittaluga S, et al. B-cell lymphoma in a patient with complete interferon gamma receptor 1 deficiency. J Clin Immunol. 2013;33(6): $1062-6$.
7. Roesler J, Horwitz ME, Picard C, Bordigoni P, Davies G, Koscielniak E, et al. Hematopoietic stem cell transplantation for complete IFN-gamma receptor 1 deficiency: a multi-institutional survey. J Pediatr. 2004;145(6):806-12.

8. de Bruin AM, Voermans C, Nolte MA. Impact of interferon-gamma on hematopoiesis. Blood. 2014;124(16):2479-86.

9. Edeer KN, Boisson-Dupuis S, Aksu G, Bustamante J, Kandiloglu $\mathrm{G}$, Ozsan N, et al. Granulomatous skin lesions, severe scrotal and lower limb edema due to mycobacterial infections in a child with complete IFN-gamma receptor-1 deficiency. Immunotherapy. 2012;4(11):1121-7.

10. Jouanguy E, Dupuis S, Pallier A, Doffinger R, Fondaneche MC, Fieschi $\mathrm{C}$, et al. In a novel form of IFN-gamma receptor 1 deficiency, cell surface receptors fail to bind IFN-gamma. J Clin Invest. 2000;105(10):1429-36.

11. Dorman SE, Uzel G, Roesler J, Bradley JS, Bastian J, Billman G, et al. Viral infections in interferon-gamma receptor deficiency. J Pediatr. 1999;135(5):640-3.

12. Holland SM, Dorman SE, Kwon A, Pitha-Rowe IF, Frucht DM, Gerstberger SM, et al. Abnormal regulation of interferon-gamma, interleukin-12, and tumor necrosis factor-alpha in human interferon-gamma receptor 1 deficiency. J Infect Dis. 1998;178(4): $1095-104$

13. Horwitz ME, Uzel G, Linton GF, Miller JA, Brown MR, Malech HL, et al. Persistent Mycobacterium avium infection following nonmyeloablative allogeneic peripheral blood stem cell transplantation for interferon-gamma receptor-1 deficiency. Blood. 2003;102(7):2692-4.

14. Chantrain CF, Bruwier A, Brichard B, Largent V, Chapgier A, Feinberg J, et al. Successful hematopoietic stem cell transplantation in a child with active disseminated Mycobacterium fortuitum infection and interferon-gamma receptor 1 deficiency. Bone Marrow Transplant. 2006;38(1):75-6.

15. Levin M, Newport MJ, D’Souza S, Kalabalikis P, Brown IN, Lenicker HM, et al. Familial disseminated atypical mycobacterial infection in childhood: a human mycobacterial susceptibility gene? Lancet. 1995;345(8942):79-83.

16. Newport MJ, Huxley CM, Huston S, Hawrylowicz CM, Oostra $\mathrm{BA}$, Williamson R, et al. A mutation in the interferon-gammareceptor gene and susceptibility to mycobacterial infection. $\mathrm{N}$ Engl J Med. 1996;335(26):1941-9.

17. Reuter U, Roesler J, Thiede C, Schulz A, Classen CF, Oelschlagel $\mathrm{U}$, et al. Correction of complete interferon-gamma receptor 1 deficiency by bone marrow transplantation. Blood. 2002;100(12): 4234-5.

18. Roesler J, Kofink B, Wendisch J, Heyden S, Paul D, Friedrich W, et al. Listeria monocytogenes and recurrent mycobacterial infections in a child with complete interferon-gamma-receptor (IFNgammaR1) deficiency: mutational analysis and evaluation of therapeutic options. Exp Hematol. 1999;27(9):1368-74.

19. Koscielniak E, de Boer T, Dupuis S, Naumann L, Casanova JL, Ottenhoff TH. Disseminated Mycobacterium peregrinum infection in a child with complete interferon-gamma receptor-1 deficiency. Pediatr Infect Dis J. 2003;22(4):378-80.

20. Olbrich P, Martinez-Saavedra MT, Perez-Hurtado JM, Sanchez C, Sanchez B, Deswarte C, et al. Diagnostic and therapeutic challenges in a child with complete interferon-gamma receptor 1 deficiency. Pediatr Blood Cancer. 2015;62(11):2036-9.

21. Vesterhus P, Holland SM, Abrahamsen TG, Bjerknes R. Familial disseminated infection due to atypical mycobacteria with childhood onset. Clin Infect Dis. 1998;27(4):822-5.

22. Bax HI, Freeman AF, Ding L, Hsu AP, Marciano B, Kristosturyan $\mathrm{E}$, et al. Interferon alpha treatment of patients with impaired interferon gamma signaling. J Clin Immunol. 2013;33(5):991-1001.

23. Pierre-Audigier C, Jouanguy E, Lamhamedi S, Altare F, Rauzier J, Vincent V, et al. Fatal disseminated Mycobacterium smegmatis 
infection in a child with inherited interferon gamma receptor deficiency. Clin Infect Dis. 1997;24(5):982-4.

24. Altare F, Jouanguy E, Lamhamedi-Cherradi S, Fondaneche MC, Fizame C, Ribierre F, et al. A causative relationship between mutant IFNgR1 alleles and impaired cellular response to IFNgamma in a compound heterozygous child. Am J Hum Genet. 1998;62(3):723-6.

25. Wang Q, Xia W, Zhao D. Interferon-gamma receptor 1 deficiency in a 19-month-old child: case report and literature review. Zhonghua Er Ke Za Zhi. 2014;52(5):387-91.

26. Jouanguy E, Altare F, Lamhamedi S, Revy P, Emile JF, Newport M, et al. Interferon-gamma-receptor deficiency in an infant with fatal bacille Calmette-Guerin infection. N Engl J Med. 1996;335(26): 1956-61.

27. Cunningham JA, Kellner JD, Bridge PJ, Trevenen CL, Mcleod DR, Davies HD. Disseminated bacille Calmette-Guerin infection in an infant with a novel deletion in the interferon-gamma receptor gene. Int J Tuberc Lung Dis. 2000;4(8):791-4.

28. De GR, Van Dongen JJ, Neijens HJ, Hooijkaas H, Drexhage HA. Familial disseminated atypical mycobacterial infection in childhood. Lancet. 1995;345(8955):993.

29. Noordzij JG, Hartwig NG, Verreck FA, De Bruin-Versteeg S, De BT, Van Dissel JT, et al. Two patients with complete defects in interferon gamma receptor-dependent signaling. J Clin Immunol. 2007;27(5):490-6.

30. Prando C, Boisson-Dupuis S, Grant AV, Kong XF, Bustamante J, Feinberg $\mathrm{J}$, et al. Paternal uniparental isodisomy of chromosome 6 causing a complex syndrome including complete IFN-gamma receptor 1 deficiency. Am J Med Genet A. 2010;152A(3):622-9.

31. Hartwig NG, Warris A, van de Vosse E, van der Zanden AG, Schulin-Casonato T, van Ingen J, et al. "Mycobacterium tilburgii" infection in two immunocompromised children: importance of molecular tools in culture-negative mycobacterial disease diagnosis. $\mathbf{J}$ Clin Microbiol. 2011;49(12):4409-11.

32. Tsolia MN, Chapgier A, Taprantzi P, Servitzoglou M, Tassios I, Spyridis N, et al. Disseminated nontuberculous mycobacterial infection in a child with interferon-gamma receptor 1 deficiency. Eur J Pediatr. 2006;165(7):458-61.

33. Marazzi MG, Chapgier A, Defilippi AC, Pistoia V, Mangini S, Savioli C, et al. Disseminated Mycobacterium scrofulaceum infection in a child with interferon-gamma receptor 1 deficiency. Int $\mathrm{J}$ Infect Dis. 2010;14(2):e167-70.

34. Dorman SE, Holland SM. Interferon-gamma and interleukin-12 pathway defects and human disease. Cytokine Growth Factor Rev. 2000;11(4):321-33.
35. Rosenzweig S, Dorman SE, Roesler J, Palacios J, Zelazko M, Holland SM. 561del4 defines a novel small deletion hotspot in the interferon-gamma receptor 1 chain. Clin Immunol. 2002;102(1):25-7.

36. Tesi B, Sieni E, Neves C, Romano F, Cetica V, Cordeiro AI, et al. Hemophagocytic lymphohistiocytosis in 2 patients with underlying IFN-gamma receptor deficiency. J Allergy Clin Immunol. 2015;135(6):1638-41.

37. Ward CM, Jyonouchi H, Kotenko SV, Smirnov SV, Patel R, Aguila $\mathrm{H}$, et al. Adjunctive treatment of disseminated Mycobacterium avium complex infection with interferon alpha- $2 \mathrm{~b}$ in a patient with complete interferon-gamma receptor R1 deficiency. Eur J Pediatr. 2007;166(9):981-5.

38. Galal N, Boutros J, Marsafy A, Kong XF, Feinberg J, Casanova JL, et al. Mendelian susceptibility to mycobacterial disease in egyptian children. Mediterr J Hematol Infect Dis. 2012;4(1):e2012033.

39. van de Wetering D, de Paus RA, Van Dissel JT, van de Vosse E. Functional analysis of naturally occurring amino acid substitutions in human IFN- $\gamma$ R1. Mol Immunol. 2010;47(5):1023-30.

40. Quispel WT, Stegehuis-Kamp JA, Santos S, van Wengen A, Dompeling E, Egeler RM, et al. Intact IFN- $\gamma$ R1 expression and function distinguishes Langerhans Cell Histiocytosis from Mendelian Susceptibility to Mycobacterial Disease. J Clin Immunol. 2014;34(1):84-93.

41. Fieschi C, Dupuis S, Picard C, Smith CI, Holland SM, Casanova JL. High levels of interferon gamma in the plasma of children with complete interferon gamma receptor deficiency. Pediatrics. 2001;107(4):E48.

42. Kotenko SV, Izotova LS, Mirochnitchenko OV, Esterova E, Dickensheets H, Donnelly RP, et al. Identification, cloning, and characterization of a novel soluble receptor that binds IL-22 and neutralizes its activity. J Immunol. 2001;166(12):7096-103.

43. Martin JC, Beriou G, Heslan M, Chauvin C, Utriainen L, Aumeunier A, et al. Interleukin-22 binding protein (IL-22BP) is constitutively expressed by a subset of conventional dendritic cells and is strongly induced by retinoic acid. Mucosal Immunol. 2014;7(1):101-13.

44. Dumoutier L, Lejeune D, Colau D, Renauld JC. Cloning and characterization of IL-22 binding protein, a natural antagonist of IL-10related $\mathrm{T}$ cell-derived inducible factor/IL-22. J Immunol. 2001;166(12):7090-5.

45. Rottman M, Soudais C, Vogt G, Renia L, Emile JF, Decaluwe $\mathrm{H}$, et al. IFN-gamma mediates the rejection of haematopoietic stem cells in IFN-gammaR1-deficient hosts. PLoS Med. 2008;5(1):e26. 